\title{
Atmospheric Chemistry of Alcohols
}

\author{
Daniel Grosjean \\ DGA, Inc., 4526 Telephone Road, Suite 205, Ventura, CA 93003 USA
}

Received: September 7, 1996

\begin{abstract}
A química atmosférica dos álcoois, os quais são largamente empregados como combustíveis de veículos leves (como o etanol no Brasil) e solventes industriais, foi revista com o foco centralizado em seus aspectos de cinética e mecanismos de reação. A oxidação dos álcoois na atmosfera envolve sua reação com radicais hidroxil $(\mathrm{OH})$. São apresentadas constantes de velocidade para a reação álcool-OH de 33 álcoois saturados, incluindo compostos mono e difuncionais. As meias-vidas atmosféricas são, respectivamente, de uma semana para metanol e t-butil álcool, 2,5 dias para etanol, e de 8-15 h para outros álcoois. São descritos estudos de laboratório para os produtos de reações álcool-OH, e mecanismos são assinalados. Os produtos que predominam são o formaldeído para o metanol, acetaldeído para etanol, acetona para 2-propanol, 2-butanona e acetaldeído para o 2-butanol e acetona e formaldeído para o t-butil álcool.

A reação de $\mathrm{OH}$ com os álcoois envolve a abstração de um átomo de hidrogênio da ligação C-H, ao passo que na ligação O-H esta abstração é negligível. Os radicais alquil (R) e $\alpha$-hidroxialquil assim formados reagem então com oxigênio. Essa reação envolve adição para os radicais alquil ( $\mathrm{R}$ $+\mathrm{O}_{2} \rightarrow \mathrm{RO}_{2}$ ) e abstração de $\mathrm{H}$ dos radicais $\alpha$-hidroxialquil (ex. etanol $+\mathrm{OH} \rightarrow \mathrm{CH}_{3} \mathrm{CHOH}$, $\left.\mathrm{CH}_{3} \mathrm{CHOH}+\mathrm{O}_{2} \rightarrow \mathrm{HO}_{2}+\mathrm{CH}_{3} \mathrm{CHO}\right)$. A sequência de reações etanol $\rightarrow$ acetaldeído $\rightarrow$ nitrato de peroxiacetila $\left(\mathrm{PAN}, \mathrm{CH}_{3} \mathrm{C}(\mathrm{O}) \mathrm{OONO}_{2}\right)$ é descrita, sendo de grande relevância para a poluição atmosférica urbana no Brasil.

Finalmente, recomenda-se que se façam estudos adicionais dos produtos, de maneira a desenvolver uma melhor compreensão da química atmosférica dos álcoois, e de seu papel na qualidade do ar urbano e regional.
\end{abstract}

The atmospheric chemistry of alcohols, which are widely used as motor vehicle fuels (e.g. ethanol in Brazil) and as industrial solvents, has been reviewed with focus on kinetic data and on reaction mechanisms. Oxidation of alcohols in the atmosphere involves their reaction with the hydroxyl radical $(\mathrm{OH})$. Alcohol-OH reaction rate constants are presented for 33 saturated alcohols including monofunctional and difunctional compounds. The corresponding atmospheric half-lives are one week for methanol and t-butyl alcohol, 2.5 days for ethanol, and 8-15 h for other alcohols. Laboratory studies of alcohol-OH reaction products are described and reaction mechanisms are outlined. Major products are formaldehyde from methanol, acetaldehyde from ethanol, acetone from 2-propanol, 2-butanone and acetaldehyde from 2-butanol and acetone and formaldehyde from t-butyl alcohol.

The reaction of $\mathrm{OH}$ with alcohols involves $\mathrm{H}$-atom abstraction from $\mathrm{C}-\mathrm{H}$ bonds; $\mathrm{H}$-atom abstraction from the $\mathrm{O}-\mathrm{H}$ bond is negligible. The alkyl radicals $(\mathrm{R})$ and $\alpha$-hydroxyalkyl radicals thus formed react with oxygen. This reaction involves addition for alkyl radicals $\left(\mathrm{R}+\mathrm{O}_{2} \rightarrow \mathrm{RO}_{2}\right)$ and $\mathrm{H}$-atom abstraction for $\alpha$-hydroxyalkyl radicals $($ e.g. ethanol $+\mathrm{OH} \rightarrow \mathrm{CH} 3 \mathrm{CHOH}, \mathrm{CH} 3 \mathrm{CHOH}$ $\left.+\mathrm{O}_{2} \rightarrow \mathrm{HO}_{2}+\mathrm{CH}_{3} \mathrm{CHO}\right)$. The reaction sequence ethanol $\rightarrow$ acetaldehyde $\rightarrow$ peroxyacetyl nitrate ( $\mathrm{PAN}, \mathrm{CH}_{3} \mathrm{C}(\mathrm{O}) \mathrm{OONO}_{2}$ ) is described and is relevant to urban air pollution in Brazil.

Recommendation is made to carry out additional product studies in order to develop a better understanding of the atmospheric chemistry of alcohols and of their role in on urban and regional air quality.

Keywords: alcohols, atmospheric chemistry, kinetics, reaction mechanisms

Phone 1-805-644-0125, FAX 1-805-644-0142. Also Professor Visitante, Programa de Pós-Graduação em Química, Instituto de Química, Universidade Federal da Bahia, Campus Universitário de Ondina, 40170-290, Salvador - Bahia, Brazil 


\section{Introduction}

It has become increasingly important to understand the atmospheric chemistry of alcohols in the context of urban and regional air quality. Alcohols, saturated and unsaturated, are emitted into the atmosphere by vegetation ${ }^{1-3}$. These biogenic emissions play an important role in the chemistry of the troposphere, especially in rainforest ecosystems such as the Amazon ${ }^{1}$. Saturated alcohols have long been used in large quantities as industrial solvents. Saturated alcohols have also been used as motor vehicle fuels and fuel additives. Ethanol, which has been used as a fuel since the invention of the internal combustion engine $(\mathrm{N}$. A. Otto used ethanol in his classical combustion engine tests in 1897), is now a major component of light-duty vehicle fuels in many countries. In Brazil, which is the only country in the world where a nationwide, large-scale alcohol fuel program has been implemented, approximately 4 million automobiles run on neat ethanol and approximately 9 million automobiles run on an ethanol-gasoline mixture that contains a large fraction of ethanol, $c a$. 22 percent. In the United States, the 1990 Amendments to the Clean Air Act required that oxygenated compounds be added to gasoline in urban areas that did not meet national ambient air quality standards for carbon monoxide (CO) and for ozone $\left(\mathrm{O}_{3}\right)$. This has generally been achieved by blending about 7 percent ethanol or about 15 percent of the ether methylt-butyl ether (MTBE) with gasoline. Other alcohols including methanol and t-butyl alcohol (TBA) and other ethers including ethyl-t-butyl ether (ETBE) have been used for many years or are under consideration as oxygenated fuels and fuel additives.

Not surprisingly when considerable monetary investments and profits are at stake, scientific issues have not played a major role in the energy policy decisions that have been made regarding alcohols and other oxygenated fuels. Perceived benefits and possible drawbacks of oxygenated fuels will undoubtedly continue to be controversial topics in future policy debates ${ }^{4}$. It is not our intent here to discuss the merits and disadvantages of alcohol fuels. The purpose of this article is to review the atmospheric chemistry of alcohols with focus on the following objectives:

- to compile available kinetic data that can be used to calculate the persistence of alcohols in the atmosphere.

- to review data from laboratory studies of reaction products, and to outline the mechanisms of the photochemical oxidation of alcohols in the atmosphere.

- to identify knowledge gaps and, when appropriate, to make suggestions for future research.

In this article, we will not consider the atmospheric chemistry of unsaturated alcohols. These compounds, which are important biogenic emissions ${ }^{1-3}$, are hydroxysubstituted alkenes (e.g. allyl alcohol, $\mathrm{CH}_{2}=\mathrm{CHCH}_{2} \mathrm{OH}$; cis-3-hexen-1-ol (leaf alcohol) $\mathrm{CH}_{3} \mathrm{CH}_{2} \mathrm{CH}=\mathrm{CHCH}_{2}$
$\mathrm{CH}_{2} \mathrm{OH}$ ). The atmospheric oxidation of unsaturated alcohols is similar to that of alkenes, i.e. the important reactions involve the unsaturated carbon-carbon bond and not the alcohol functional group ${ }^{5,6}$. This review will focus on the atmospheric chemistry of saturated alcohols (primary: $\mathrm{RCH}_{2} \mathrm{OH}$; secondary: $\mathrm{R}_{1} \mathrm{CHOHR}_{2}$; tertiary: $\mathrm{R}_{1} \mathrm{R}_{2} \mathrm{R}_{3} \mathrm{COH}$, where $\mathrm{R}=$ alkyl groups). The atmospheric chemistry of ethers, which along with alcohols constitute an important group of oxygenated fuels, has been reviewed elsewhere ${ }^{7}$.

\section{Kinetic Data for the OH-Alcohol Reaction}

Examination of available kinetic data ${ }^{8}$ indicates that the following reactions of alcohols are slow and are of negligible importance in the atmosphere: photolysis, reaction with ozone, and reaction with the nitrate radical. The only chemical process by which alcohols are removed from the atmosphere is their reaction with the hydroxyl radical $(\mathrm{OH})$.

\section{Reaction rate constants}

Rate constants for the gas phase reaction of alcohols with $\mathrm{OH}$ at ambient temperature are compiled in Table 1. Kinetic data published prior to $c a$. 1985 have been taken from the 1986 review of Atkinson ${ }^{9}$. Data published during the last decade (1986-1996) are from the original references $^{10-18}$, which are listed in Table 1 for each alcohol studied. The kinetic data listed in Table 1 include $\mathrm{OH}$ reaction rate constants for thirty three alcohols, of which nineteen are $\mathrm{C}_{1}-\mathrm{C}_{8}$ monofunctional alcohols (primary, secondary and tertiary) and fourteen are difunctional alcohols including diols, hydroxy ethers, and hydroxycarbonyls.

For all but two of the alcohols listed, reaction with $\mathrm{OH}$ involves $\mathrm{H}$-atom abstraction from a $\mathrm{C}-\mathrm{H}$ bond (major) or from the $\mathrm{O}-\mathrm{H}$ bond (minor and often negligible) as is discussed in more detail below. For allyl alcohol and hydroxyacetaldehyde, reaction with $\mathrm{OH}$ involves different mechanisms, i.e. $\mathrm{OH}$ addition at the $\mathrm{C}=\mathrm{C}$ bond for allyl alcohol $^{5,6}$ and mostly (ca. 78\%) H-atom abstraction from the carbonyl carbon for hydroxyacetaldehyde ${ }^{15}$.

For four of the alcohols listed in Table 1, the OH-alcohol reaction rate constant has been measured over a range of temperatures and the corresponding Arrhenius equations $\left(\mathrm{k}=\mathrm{Ae}^{-\mathrm{E} / \mathrm{RT}}\right)$ have been reported ${ }^{11,13}$. This information is summarized in Table 2 and indicates that, in the range of temperatures relevant to the atmosphere, temperature has only a modest effect on the $\mathrm{OH}$-alcohol reaction rate constants.

\section{Mechanistic implications of kinetic data}

The kinetic data listed in Table 1 indicate that the reaction of saturated alcohols with $\mathrm{OH}$ at ambient temperature involves $\mathrm{H}$-atom abstraction from a $\mathrm{C}-\mathrm{H}$ bond rather than from the $\mathrm{O}-\mathrm{H}$ bond. This is consistent with theory since the $\mathrm{O}-\mathrm{H}$ bond (bond strength $=104 \mathrm{kcal} \mathrm{mol}^{-1}$ ) is 
Table 1. Kinetic data for the reaction of alcohols with the hydroxyl radical and estimated half-lives of alcohols in the atmosphere.

\begin{tabular}{|c|c|c|c|c|}
\hline & Alcohol & $\begin{array}{l}\text { OH reaction rate constant } \\
\text { at } c a .298 \mathrm{~K} \text { (units: } 10^{-12} \\
\mathrm{~cm}^{3} \text { molecule } \mathrm{s}^{-1} \text { ) }\end{array}$ & reference & $\begin{array}{c}\text { atmospheric } \\
\text { half-life - days - } \\
\text { when } \\
\mathrm{OH}=1.0 \times 10^{6} \\
\text { molecule } \mathrm{cm}^{-3}\end{array}$ \\
\hline \multicolumn{5}{|l|}{ monofunctional alcohols: } \\
\hline methanol & $\mathrm{CH}_{3} \mathrm{OH}$ & $\begin{array}{l}0.93 \pm 0.04 \\
0.86 \pm 0.05 \\
0.90 \pm 0.09\end{array}$ & $\begin{array}{l}10 \\
11 \\
18\end{array}$ & 8.6 \\
\hline methanol - $\mathrm{d}_{3}$ & $\mathrm{CD}_{3} \mathrm{OH}$ & $0.43 \pm 0.02$ & 10 & - \\
\hline ethanol & $\mathrm{CH}_{3} \mathrm{CH}_{2} \mathrm{OH}$ & $\begin{array}{l}3.33 \pm 0.23 \\
3.04 \pm 0.25\end{array}$ & $\begin{array}{l}11 \\
18\end{array}$ & 2.4 \\
\hline 1-propanol & $\mathrm{CH}_{3} \mathrm{CH}_{2} \mathrm{CH}_{2} \mathrm{OH}$ & $\begin{array}{l}5.34 \pm 0.29 \\
5.64 \pm 0.48\end{array}$ & $\begin{array}{l}11 \\
18\end{array}$ & 1.5 \\
\hline 2-propanol (isopropyl alcohol) & $\mathrm{CH}_{3} \mathrm{CHOHCH}_{3}$ & $\begin{array}{l}5.81 \pm 0.34 \\
5.69 \pm 1.09\end{array}$ & $\begin{array}{l}11 \\
18\end{array}$ & 1.4 \\
\hline 1-butanol & $\mathrm{CH}_{3} \mathrm{CH}_{2} \mathrm{CH}_{2} \mathrm{CH}_{2} \mathrm{OH}$ & $\begin{array}{l}8.31 \pm 0.63 \\
7.80 \pm 0.20\end{array}$ & $\begin{array}{l}11 \\
18\end{array}$ & 0.96 \\
\hline 2-butanol & $\mathrm{CH}_{3} \mathrm{CHOHCH}_{2} \mathrm{CH}_{3}$ & no data (a) & - & 1.0 (a) \\
\hline 2-methyl-2-butanol (t-butyl alcohol) & $\left(\mathrm{CH}_{3}\right)_{3} \mathrm{COH}$ & $1.07 \pm 0.08$ & 13 & 7.5 \\
\hline 1-pentanol & $\mathrm{CH}_{3}\left(\mathrm{CH}_{2}\right)_{3} \mathrm{CH}_{2} \mathrm{OH}$ & $\begin{array}{l}10.8 \pm 1.1 \\
12.0 \pm 1.6\end{array}$ & $\begin{array}{l}11 \\
18\end{array}$ & 0.74 \\
\hline 2-pentanol & $\mathrm{CH}_{3} \mathrm{CHOHCH}_{2} \mathrm{CH}_{2} \mathrm{CH}_{3}$ & $11.8 \pm 0.8$ & 12 & 0.68 \\
\hline 3-pentanol & $\mathrm{CH}_{3} \mathrm{CH}_{2} \mathrm{CHOHCH}_{2} \mathrm{CH}_{3}$ & $12.2 \pm 0.7$ & 12 & 0.65 \\
\hline 3-methyl-2-butanol & $\left(\mathrm{CH}_{3}\right)_{2} \mathrm{CHCHOHCH}_{3}$ & $12.4 \pm 0.7$ & 12 & 0.64 \\
\hline cyclopentanol & cyclo- $\left[\left(\mathrm{CH}_{2}\right)_{4} \mathrm{CH}\right] \mathrm{OH}$ & $10.7 \pm 0.7$ & 12 & 0.75 \\
\hline 1-hexanol & $\mathrm{CH}_{3}\left(\mathrm{CH}_{2}\right)_{4} \mathrm{CH}_{2} \mathrm{OH}$ & $\begin{array}{l}12.4 \pm 0.7 \\
12.2 \pm 2.4\end{array}$ & 12 & 0.64 \\
\hline 2-hexanol & $\mathrm{CH}_{3} \mathrm{CHOH}\left(\mathrm{CH}_{2}\right) \mathrm{cCH}_{2} \mathrm{OH}$ & $12.1 \pm 0.7$ & 18 & 0.66 \\
\hline 1-heptanol & $\mathrm{CH}_{3}\left(\mathrm{CH}_{2}\right)_{5} \mathrm{CH}_{2} \mathrm{OH}$ & $\begin{array}{c}13.6 \pm 1.3 \\
13.7 \pm 1.5\end{array}$ & $\begin{array}{l}12 \\
18\end{array}$ & 0.59 \\
\hline 2,4-dimethyl-2-pentanol & $\left(\mathrm{CH}_{3}\right)_{2} \mathrm{C}(\mathrm{OH}) \mathrm{CH}_{2} \mathrm{CH}\left(\mathrm{CH}_{3}\right)_{2}$ & $11.4 \pm 3.0$ & 14 & 0.70 \\
\hline 3,5-dimethyl-3-hexanol & $\mathrm{CH}_{3} \mathrm{CH}_{2} \mathrm{COH}\left(\mathrm{CH}_{3}\right) \mathrm{CH}_{2} \mathrm{CH}\left(\mathrm{CH}_{3}\right)_{2}$ & $13.6 \pm 3.6$ & 18 & 0.59 \\
\hline 1-octanol & $\mathrm{CH}_{3}\left(\mathrm{CH}_{2}\right)_{6} \mathrm{CH}_{2} \mathrm{OH}$ & $14.4 \pm 1.5$ & 18 & 0.55 \\
\hline \multicolumn{4}{|l|}{ difunctional alcohols: } & \\
\hline allyl aocohol & $\mathrm{CH}_{2}=\mathrm{CHCH}_{2} \mathrm{OH}$ & $25.9 \pm 3.3(b, c)$ & 9 & $0.31(\mathrm{e})$ \\
\hline \multicolumn{5}{|l|}{ hydroxycarbonyls: } \\
\hline hidroxyacetaldehyde & $\mathrm{HOCH}_{2} \mathrm{CHO}$ & $10.0(\mathrm{~d})$ & 15 & $0.80(\mathrm{f})$ \\
\hline hydroxyacetone & $\mathrm{CH}_{3} \mathrm{C}(\mathrm{O}) \mathrm{CH}_{2} \mathrm{OH}$ & $3.0 \pm 0.3$ & 16 & 2.7 (f) \\
\hline 4-hydroxy-4-methyl-2-pentanone & $\mathrm{CH}_{3} \mathrm{C}(\mathrm{O}) \mathrm{CH}_{2} \mathrm{OH}\left(\mathrm{CH}_{3}\right)_{2}$ & $4.0 \pm 1.2$ & 14 & 2.0 (f) \\
\hline
\end{tabular}


diols:

1,2-ethane diol

1,2-propane diol

2-hydroxyethyl ehter

hydroxyethers:

2-methoxyethanol

2-ethoxyethanol

2-butoxyethanol

3-ethoxy-1-propanol

3-methoxy-1-butanol

other difunctional alcohols:

2-(dimethylamino)ethanol

2-chloroethanol

\author{
$\mathrm{HOCH}_{2} \mathrm{CH}_{2} \mathrm{OH}$ \\ $\mathrm{HOCH}_{2} \mathrm{CHOHCH}_{3}$ \\ $\mathrm{HOCH}_{2} \mathrm{CH}_{2} \mathrm{OCH}_{2} \mathrm{CH}_{2} \mathrm{OH}$
}

$\mathrm{CH}_{3} \mathrm{OCH}_{2} \mathrm{CH}_{2} \mathrm{OH}$

$\mathrm{CH}_{3} \mathrm{CH}_{2} \mathrm{OH}$

$\mathrm{CH}_{3}\left(\mathrm{CH}_{2}\right)_{3} \mathrm{OCH}_{2} \mathrm{CH}_{2} \mathrm{OH}$

$\mathrm{CH}_{3} \mathrm{CH}_{2} \mathrm{O}\left(\mathrm{CH}_{2}\right)_{2} \mathrm{CH}_{2} \mathrm{OH}$

$\mathrm{CH}_{3} \mathrm{CH}\left(\mathrm{OCH}_{3}\right) \mathrm{CH}_{2} \mathrm{CH}_{2} \mathrm{OH}$

$\begin{array}{ccc}7.7 \pm 1.1 & 9 & 1.04 \\ 12 \pm 1 & 9 & 0.67 \\ 30 \pm 2 & 9 & 0.27\end{array}$

$\begin{array}{lll}12.5 \pm 0.7 & 16 & 0.64\end{array}$

$\begin{array}{lll}18.7 \pm 2.0 & 16 & 0.43\end{array}$

$\begin{array}{lll}23.1 \pm 0.9 & 16 & 0.35\end{array}$

$22.0 \pm 1.3 \quad 16 \quad 0.30$

$\begin{array}{lll}23.6 \pm 1.6 & 16 & 0.34\end{array}$

(a) estimated ${ }^{23}, \mathrm{k}=8.0 \times 10^{-12} \mathrm{~cm}^{3}$ molecule $\mathrm{s}^{-1}$.

(b) at $440 \mathrm{~K}$.

(c) reaction with $\mathrm{OH}$ involves $\mathrm{OH}$ addition at $\mathrm{C}=\mathrm{C}_{\text {bond }}$.

(d) reaction with $\mathrm{OH}$ involves mostly $(c a .78 \%) \mathrm{H}$-atom abstraction from carbonyl carbon ${ }^{15}$.

(e) also removed from the atmosfere by reaction with ozone ${ }^{5,6}$.

(f) also removed from atmosfere by photolysis ${ }^{8,9}$.

Table 2. Arrhenius parameters for the gas phase reaction of $\mathrm{OH}$ with alcohols.

\begin{tabular}{lcc}
\hline Alcohol & rate constant $\left(\mathrm{cm}^{3}\right.$ molecule $\left.\mathrm{s}^{-1 \mathrm{a}}\right)$ & Reference \\
\hline Methanol & $\mathrm{k}=(4.8 \pm 1.2) \times 10^{-12} \mathrm{e}^{(-480 \pm 70 / \mathrm{T})}$ & 11 \\
Ethanol & $\mathrm{k}=(7.4 \pm 3.2) \times 10^{-12} \mathrm{e}^{(-240 \pm 110 / \mathrm{T})}$ & 11 \\
2-Propanol & $\mathrm{k}=(5.8 \pm 1.9) \times 10^{-12} \mathrm{e}^{(-30 \pm 90 / \mathrm{T})}$ & 11 \\
2-Methyl-2-propanol (t-butyl alcohol) & $\mathrm{k}=(3.3 \pm 1.6) \times 10^{-12} \mathrm{e}^{(-310 \pm 150 / \mathrm{T})}$ & 13 \\
\hline
\end{tabular}

(a) from linear regression of kinetic measurements at $\mathrm{T}=240-440 \mathrm{~K}$; stated uncertainties are two standard deviations.

stronger than the $\mathrm{C}-\mathrm{H}$ bond (bond strength $=94 \mathrm{kcal}$ mol -1 in methanol). If the initial step in the $\mathrm{OH}$-alcohol reaction involves $\mathrm{H}$-atom abstraction from $\mathrm{C}$-H bonds, then (a) $\mathrm{OH}$ reacts faster with methanol than with methanol- $\mathrm{d}_{3}$ $\left(\mathrm{CD}_{3} \mathrm{OH}\right.$ ), as observed ${ }^{10}$ (the $\mathrm{C}$-D bond is stronger than the $\mathrm{C}-\mathrm{H}$ bond), (b) the $\mathrm{OH}$ reaction rate constants for the series $\mathrm{CH}_{3}\left(\mathrm{CH}_{2}\right)_{\mathrm{n}} \mathrm{OH}$ increases from methanol $(\mathrm{n}=0)$ to 1 -octanol $(\mathrm{n}=7)$, as observed, ${ }^{11,12,18}$ due to the increasing number of secondary $\mathrm{C}-\mathrm{H}$ bonds, and (c) the reaction of $\mathrm{OH}$ with t-butyl alcohol, which contains only primary (and therefore stronger) $\mathrm{C}-\mathrm{H}$ bonds, is slower, again as observed, than that of $\mathrm{OH}$ with 1-butanol and 2-butanol which contain weaker secondary and tertiary $\mathrm{C}-\mathrm{H}$ bonds.

Thus, the reaction of alcohols with $\mathrm{OH}$ can be written as follows:

$$
\mathrm{RCH}_{2} \mathrm{OH}+\mathrm{OH} \longrightarrow \mathrm{H}_{2} \mathrm{O}+\mathrm{RCHOH}
$$

and the reaction pathway that involves $\mathrm{H}$-atom abstraction from the $\mathrm{O}-\mathrm{H}$ bond:

$$
\mathrm{RCH}_{2} \mathrm{OH}+\mathrm{OH} \longrightarrow \mathrm{H}_{2} \mathrm{O}+\mathrm{RCH}_{2} \mathrm{O}
$$

is negligible under atmospheric conditions. This important mechanistic aspect of the alcohol-OH reaction is further supported by data for the reaction of alcohols with chlorine atoms. This reaction is expected to be similar to the alcohol- $\mathrm{OH}$ reaction since both $\mathrm{OH}$ and $\mathrm{Cl}$ are electrophiles. Indeed kinetic and product studies of the alcohol-Cl reaction ${ }^{19,20}$ have shown that $\mathrm{H}$-atom abstraction involves $\mathrm{C}-\mathrm{H}$ bonds and not the $\mathrm{O}-\mathrm{H}$ bond:

$$
\mathrm{RCH}_{2} \mathrm{OH}+\mathrm{Cl} \longrightarrow \mathrm{HCl}+\mathrm{RCHOH}
$$

Accordingly, the initial step in the reaction of methanol with $\mathrm{OH}$ can be written as follows:

$$
\mathrm{CH}_{3} \mathrm{OH}+\mathrm{OH} \longrightarrow \mathrm{H}_{2} \mathrm{O}+\mathrm{CH}_{2} \mathrm{OH}
$$


where reaction (2) yields the simplest $\alpha$-hydroxyalkyl radical, i.e. the hydroxymethyl radical $\mathrm{CH}_{2} \mathrm{OH}$. For higher molecular weight alcohols, reaction with $\mathrm{OH}$ may involve $\mathrm{H}$-atom abstraction from several $\mathrm{C}-\mathrm{H}$ bonds. In this case the major pathway involves $\mathrm{H}$-atom abstraction from the weakest $\mathrm{C}-\mathrm{H}$ bond, i.e. $\mathrm{H}$-atom abstraction from tertiary $\mathrm{C}-\mathrm{H}$ bonds preferentially to $\mathrm{H}$-atom abstraction from secondary $\mathrm{C}-\mathrm{H}$ bonds, and $\mathrm{H}$-atom abstraction from secondary $\mathrm{C}-\mathrm{H}$ bonds preferentially to $\mathrm{H}$-atom abstraction from primary $\mathrm{C}-\mathrm{H}$ bonds. Thus, for ethanol:

$$
\begin{gathered}
\mathrm{CH}_{3} \mathrm{CH}_{2} \mathrm{OH}+\mathrm{OH} \underset{\mathrm{H}_{2} \mathrm{O}+}{\longrightarrow} \underset{\mathrm{CH}_{3} \mathrm{CHOH} \text { (major) }}{\longrightarrow} \\
\longrightarrow \mathrm{H}_{2} \mathrm{O}+\mathrm{CH}_{2} \mathrm{CH}_{2} \mathrm{OH} \text { (minor) }
\end{gathered}
$$

Similarly for 1-propanol:

$$
\begin{gathered}
\mathrm{CH}_{3} \mathrm{CH}_{2} \mathrm{CH}_{2} \mathrm{OH}+\mathrm{OH} \longrightarrow \mathrm{H}_{2} \mathrm{O}+ \\
+\mathrm{CH}_{3} \mathrm{CH}_{2} \mathrm{CHOH} \text { (major) } \\
\longrightarrow \mathrm{H}_{2} \mathrm{O}+\mathrm{CH}_{3} \mathrm{CHCH}_{2} \mathrm{OH} \text { (major) } \\
\longrightarrow \mathrm{H}_{2} \mathrm{O}+\mathrm{CH}_{2} \mathrm{CH}_{2} \mathrm{CH}_{2} \mathrm{OH} \text { (minor) }
\end{gathered}
$$

and for 2-propanol:

$$
\begin{gathered}
\mathrm{CH}_{3} \mathrm{CHOHCH}_{3}+\mathrm{OH} \stackrel{\mathrm{H}_{2} \mathrm{O}+\mathrm{CH}_{3} \mathrm{COHCH}_{3}}{\longrightarrow} \\
\mathrm{H}_{2} \mathrm{O}+\mathrm{CH}_{2} \mathrm{CHOHCH}_{3} \text { (minor) }
\end{gathered}
$$

For t-butyl alcohol, which contains identical primary $\mathrm{C}-\mathrm{H}$ bonds, reaction with $\mathrm{OH}$ involves only one reaction pathway:

$$
\begin{array}{ll}
(\mathrm{CH} 3)_{3} \mathrm{COH}+\mathrm{OH} \longrightarrow \mathrm{H}_{2} \mathrm{O}+ \\
+\mathrm{CH}_{2} \mathrm{C}(\mathrm{OH})\left(\mathrm{CH}_{3}\right)_{2}
\end{array}
$$

Reactions (2-6) above indicate that the reaction of $\mathrm{OH}$ with alcohols results in the formation of two types of radicals: alkyl radicals (reactions $3 b, 4 b, 4 c, 5 b$ and 6) and $\alpha$-hydroxyalkyl radicals (reactions $2,3 \mathrm{a}, 4 \mathrm{a}$ and $5 \mathrm{a}$ ). As will be discussed in the next section, these two types of radicals lead to different reaction products under atmospheric conditions.

\section{Atmospheric persistence of alcohols}

Using the kinetic data summarized in Table 1, we have calculated the atmospheric half-life of alcohols that results from their removal by reaction with $\mathrm{OH}$. These atmospheric half-lives are listed in Table 1 and have been calculated using $[\mathrm{OH}]=1.0 \times 106$ molecule $\mathrm{cm}^{-3}$; this value is representative of actual $\mathrm{OH}$ concentrations in the troposphere $^{8}$. Atmospheric half-lives thus calculated are about one week for methanol and t-butyl alcohol, two and a half days for ethanol, fifteen hours for the higher molecular weight monofunctional alcohols, and eight to fifteen hours for the hydroxyether solvents. Concentrations of $\mathrm{OH}$ in the troposphere exhibit strong diurnal variations with maxima at ca. noon and minima at night. As a result, half-lives for alcohols in the atmosphere are expected to exhibit diurnal variations that are the opposite of those of $[\mathrm{OH}]$, i.e. with minima at ca. noon and maxima at night.

While reaction with $\mathrm{OH}$ is the only known chemical removal process for alcohols in the atmosphere, physical removal processes should also be considered. These processes, for which little information is available, include dry deposition, and, on account of the solubility of alcohols in water, scavenging by hydrometeors (clouds, rain $^{21}$, fog, snow) and by water-containing aerosol particles. Should these processes be important, the atmospheric lifetimes given in Table 1 would be upper limits for the actual persistence of alcohols in the atmosphere.

\section{Product Studies and Reaction Mechanisms}

Perhaps surprisingly considering the current importance of alcohols in urban atmospheric chemistry, only a few studies have been carried out to characterize the products of the $\mathrm{OH}$-alcohol reaction $14,{ }^{22-26}$. Several of these laboratory studies have included the alcohol-chlorine atom reaction instead of, or in addition to, the alcohol-OH reaction (the two reactions involve similar mechanisms and lead to the same products, see reactions 1a and 1c). This is because the stronger electrophile $\mathrm{Cl}$ reacts with alcohols ca. 25-50 times faster than $\mathrm{OH}$ does ${ }^{18-20}$ therefore leading to higher product yields (when compared to $\mathrm{OH}$ ) for a given reaction time.

A summary of laboratory studies of the products of the alcohol-OH reaction (and / or alcohol-Cl reaction) is given in Table 3. Reaction products and the corresponding mechanisms are discussed in this section for each of the seven alcohols studied.

Reaction of alkyl radicals and $\alpha$-hydroxyalkyl radicals with $\mathrm{O}_{2}$

The discussion of reaction mechanisms for each alcohol will gain in clarity if we first compare the reactions of alkyl radicals and of $\alpha$-hydroxyalkyl radicals, even though our understanding of the atmospheric chemistry of $\alpha$-hydroxyalkyl radicals is derived to a large extent from the experimental studies that are described below. Both alkyl radicals and $\alpha$-hydroxyalkyl radicals react rapidly with oxygen $^{19,27,28}$. As a result, reaction with oxygen is their only important reaction in the atmosphere. Alkyl radicals (including those that bear an $\mathrm{OH}$ group on any carbon atom that is not the $\alpha$-carbon) react with oxygen by addition ${ }^{8,9}$, leading to a peroxy radical:

$$
\mathrm{R}+\mathrm{O}_{2} \longrightarrow \mathrm{RO}_{2}
$$

e.g. $\mathrm{CH}_{3}+\mathrm{O}_{2} \rightarrow \mathrm{CH}_{3} \mathrm{O}_{2}$, or $\mathrm{CH}_{3} \mathrm{CHOHCH}_{2}+\mathrm{O}_{2} \rightarrow$ $\mathrm{CH}_{3} \mathrm{CHOHCH}_{2} \mathrm{O}_{2}$. In contrast, $\alpha$-hydroxyalkyl radicals 
react with oxygen by $\mathrm{H}$-atom abstraction from the $\mathrm{O}-\mathrm{H}$ bond, leading to a carbonyl and the $\mathrm{HO}_{2}$ radical:

$$
\mathrm{RCHOH}+\mathrm{O}_{2} \longrightarrow \mathrm{HO}_{2}+\mathrm{RCHO}
$$

As will be seen in the following sections, the nature of the products of the $\mathrm{OH}$-alcohol reaction is dictated to a large extent by the mechanistic difference between the alkyl $+\mathrm{O}_{2}$ reaction and the $\alpha$-hydroxyalkyl $+\mathrm{O}_{2}$ reaction.

\section{Methanol}

The reaction of methanol with chlorine atoms has been studied by Ohta et $a .^{22}$ and by Whitbeck ${ }^{23}$. The only product identified was formaldehyde. As mentioned earlier, kinetic studies of the methanol- $\mathrm{OH}^{10}$ and methanol$\mathrm{Cl}^{19}$ reactions, which involved the deuterated compounds $\mathrm{CD}_{3} \mathrm{OH}$ and $\mathrm{CH}_{3} \mathrm{OD}$, indicate that the reaction involves $\mathrm{H}$-atom abstraction from $\mathrm{C}-\mathrm{H}$ and not from $\mathrm{O}-\mathrm{H}$. The relevant reactions are:

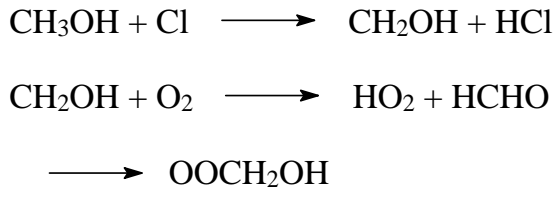

$\mathrm{OOCH}_{2} \mathrm{OH} \longrightarrow$ products including $\mathrm{HCOOH}(11)$
Formic acid was not identified, thus supporting the conclusion (see preceding paragraph) that the $\alpha$-hydroxyalkyl radical $\mathrm{CH}_{2} \mathrm{OH}$ (hydroxymethyl) reacts with oxygen by $\mathrm{H}$-atom abstraction (pathway 10a) and not by addition (pathway 10b). In the atmosphere, the oxidation of methanol can be described by two reactions, i.e. reaction with $\mathrm{OH}$ (reaction 2) followed by reaction of $\mathrm{CH}_{2} \mathrm{OH}$ with $\mathrm{O}_{2}$ to produce formaldehyde (reaction 10a).

\section{Ethanol}

To our knowledge the only study of the reaction products of ethanol is that of Carter, et al. ${ }^{24}$, who investigated the ethanol-OH and ethanol-Cl reactions. Four experiments were carried out, two with alcohol-NOx mixtures (NOx = $\mathrm{NO}+\mathrm{NO}_{2}$ ) and two with alcohol-NOx- $\mathrm{Cl}_{2}$ mixtures. Reaction products were acetaldehyde (major), formaldehyde, methyl nitrate $\left(\mathrm{CH}_{3} \mathrm{ONO}_{2}\right)$ and peroxyacetyl nitrate (PAN, $\left.\mathrm{CH}_{3} \mathrm{C}(\mathrm{O}) \mathrm{OONO}_{2}\right)$. Small amounts of ethyl nitrate $\left(\mathrm{C}_{2} \mathrm{H}_{5} \mathrm{ONO}_{2}\right)$ and of formic acid were also reported. The reactions of interest, shown below for the OH-ethanol reaction, include the three possible initial $\mathrm{H}$-atom abstraction pathways:
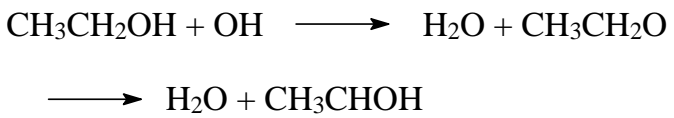

Table 3. Summary of studies of products of the alcohol-OH and alcohol-Cl reactions.

\begin{tabular}{|c|c|c|c|}
\hline Alcohol & Authors (reference) & Reaction studied (a) & Major products (b) \\
\hline \multirow[t]{2}{*}{ Methanol } & Ohta et al. (22) & $\mathrm{Cl}$ & Formaldehyde (c) \\
\hline & Ehitbeck (23) & $\mathrm{Cl}$ & Formaldehyde (c) \\
\hline Ethanol & Carter et al. (24) & $\mathrm{OH}, \mathrm{Cl}$ & acetaldehyde $(0.80 \pm 0.15)$ \\
\hline 2-propanol (isopropyl alcohol) & Ohta et al. (22) & $\mathrm{Cl}$ & acetone (c) \\
\hline 2-butanol & Carter et al. (24) & $\mathrm{OH}$ & $\begin{array}{c}\text { 2-butanone }(0.75-0.80) \\
\text { acetaldehyde }(0.12-0.16)\end{array}$ \\
\hline \multirow{2}{*}{ 2-methyl-2-propanol (t-butyl alcohol) } & Cox \& Goldstone (25) & $\mathrm{OH}$ & acetone (c) \\
\hline & Japar et al. (26) & $\mathrm{Cl}$ & acetone (1.0) \\
\hline \multicolumn{4}{|l|}{ formaldehyde (1.0) } \\
\hline \multirow[t]{2}{*}{ 2,4-dimethyl-2-pentanol } & Atkinson \& Aschmann (14) & $\mathrm{OH}$ & acetone $(0.92 \pm 0.15)$ \\
\hline & & & $\begin{array}{l}\text { 2-methyl propanal }(0.21 \pm 0.02) \\
\text { 4-hydroxy-4-methyl-2-pentanone } \\
\qquad(0.12 \pm 0.02)(\mathrm{d})\end{array}$ \\
\hline \multirow[t]{3}{*}{ 3,5-dimethyl-3-hexanol } & Atkinson \& Aschmann (14) & $\mathrm{OH}$ & acetone $(0.12 \pm 0.03)$ \\
\hline & & & 2-butanone $(0.27 \pm 0.02)$ \\
\hline & & & $\begin{array}{l}\text { 4-hydroxy-4-methyl-2-pentanone } \\
\qquad(0.25 \pm 0.02)(\mathrm{d})\end{array}$ \\
\hline
\end{tabular}

(a) $\mathrm{Cl}=$ reaction of alcohol with clorine atoms; $\mathrm{OH}=$ reaction of alcohol with hydroxyl radicals.

(b) yield (molar units) given in parenthesis when reported.

(c) only product reported.

(d) product of alkoxy radical isomerization, see text. 


\section{$\mathrm{H}_{2} \mathrm{O}+\mathrm{CH}_{2} \mathrm{CH}_{2} \mathrm{OH}$}

Reaction 12, which involves $\mathrm{H}$-atom abstraction from the $\mathrm{O}-\mathrm{H}$ bond, was calculated from the measured ethyl nitrate concentration to account for $1-3 \%$ of the overall reaction, consistent with the prediction from bond strength considerations that $\mathrm{H}$-atom abstraction from $\mathrm{O}-\mathrm{H}$ makes a negligible contribution to the overall $\mathrm{OH}$-alcohol reaction.

The hydroxyethyl radical formed in pathway $3 \mathrm{a}$ is an $\alpha$-hydroxyalkyl radical and reacts with oxygen by $\mathrm{H}$-atom abstraction to form acetaldehyde:

$$
\mathrm{CH}_{3} \mathrm{CHOH}+\mathrm{O}_{2} \longrightarrow \mathrm{CH}_{3} \mathrm{CHO}+\mathrm{HO}_{2}
$$

The yield of acetaldehyde, corrected for removal of acetaldehyde by photolysis and by reaction with $\mathrm{OH}$ (reactions of acetaldehyde are discussed below), was $80 \pm$ $15 \%{ }^{24}$. Reaction 3a, which involves $\mathrm{H}$-atom abstraction from the weaker secondary $\mathrm{C}-\mathrm{H}$ bonds, is therefore the major reaction pathway as expected from bond strength considerations. By difference, pathway $3 \mathrm{~b}$ may account for $5-35 \%$ of the overall $\mathrm{OH}$-ethanol reaction. The alkyl radical $\mathrm{CH}_{2} \mathrm{CH}_{2} \mathrm{OH}$ formed in pathway $3 \mathrm{~b}$ reacts with oxygen by addition:

$$
\mathrm{CH}_{2} \mathrm{CH}_{2} \mathrm{OH}+\mathrm{O}_{2} \longrightarrow \mathrm{OOCH}_{2} \mathrm{CH}_{2} \mathrm{OH}
$$

and the peroxy radical $\mathrm{RO}_{2}$ formed in (14a) reacts with $\mathrm{NO}$ to form $\mathrm{NO}_{2}$ and the alkoxy radical $\mathrm{RO}$ :

$$
\begin{aligned}
\mathrm{OOCH}_{2} \mathrm{CH}_{2} \mathrm{OH}+\mathrm{NO} \longrightarrow & \mathrm{NO}_{2}+ \\
& +\mathrm{OCH}_{2} \mathrm{CH}_{2} \mathrm{OH}
\end{aligned}
$$

The alkoxy radical formed in (14b) may either react with oxygen to form hydroxyacetaldehyde or decompose by cleavage of the $\mathrm{C}-\mathrm{C}$ bond to form formaldehyde:

$$
\begin{aligned}
\mathrm{OCH}_{2} \mathrm{CH}_{2} \mathrm{OH}+\mathrm{O}_{2} \longrightarrow & \mathrm{HO}_{2}+ \\
& +\mathrm{HC}(\mathrm{O}) \mathrm{CH}_{2} \mathrm{OH}(14 \mathrm{c}) \\
\mathrm{OCH}_{2} \mathrm{CH}_{2} \mathrm{OH} \longrightarrow & \mathrm{HCHO}+\mathrm{CH}_{2} \mathrm{OH} \quad(14 \mathrm{~d})
\end{aligned}
$$

and the $\alpha$-hydroxyalkyl radical $\mathrm{CH}_{2} \mathrm{OH}$ reacts with oxygen to produce formaldehyde as discussed above for methanol:

$$
\mathrm{CH}_{2} \mathrm{OH}+\mathrm{O}_{2} \longrightarrow \mathrm{HO}_{2}+\mathrm{HCHO}
$$

Carter et $a .^{24}$ did not measure hydroxyacetaldehyde and therefore the relative importance of pathways $14 \mathrm{c}$ and (14d) could not be assessed.

\section{Reactions of acetaldehyde}

Once formed in the atmosphere as a major product of the ethanol-OH reaction, acetaldehyde is removed rapidly by photolysis and by reaction with $\mathrm{OH}^{8,9}$. Photolysis leads to carbon monoxide, formaldehyde and two $\mathrm{HO}_{2}$ radicals:

$$
\mathrm{CH}_{3} \mathrm{CHO}+\mathrm{hv} \longrightarrow \mathrm{CH}_{3}+\mathrm{HCO}
$$

$$
\begin{aligned}
& \mathrm{HCO}+\mathrm{O}_{2} \longrightarrow \mathrm{CO}+\mathrm{HO}_{2} \\
& \mathrm{CH}_{3}+\mathrm{O}_{2} \longrightarrow \mathrm{CH}_{3} \mathrm{O}_{2} \\
& \mathrm{CH}_{3} \mathrm{O}_{2}+\mathrm{NO} \longrightarrow \mathrm{NO}_{2}+\mathrm{CH}_{3} \mathrm{O} \\
& \mathrm{CH}_{3} \mathrm{O}+\mathrm{O}_{2} \longrightarrow \mathrm{HO}_{2}+\mathrm{HCHO}
\end{aligned}
$$

Reaction with $\mathrm{OH}$, which involves $\mathrm{H}$-atom abstraction from the carbonyl carbon, leads to peroxyacetyl nitrate:

$$
\begin{aligned}
& \mathrm{CH}_{3} \mathrm{CHO}+\mathrm{OH} \longrightarrow \mathrm{H}_{2} \mathrm{O}+\mathrm{CH}_{3} \mathrm{CO} \\
& \mathrm{CH}_{3} \mathrm{CO}+\mathrm{O}_{2} \longrightarrow \mathrm{CH}_{3} \mathrm{CO}_{3} \\
& \mathrm{CH}_{3} \mathrm{CO}_{3}+\mathrm{NO}_{2} \longrightarrow \mathrm{CH}_{3} \mathrm{C}=\mathrm{OOOONO}_{2}(\mathrm{PAN})(16 \mathrm{c})
\end{aligned}
$$

In turn, thermal decomposition of PAN leads to $\mathrm{CO}_{2}$ and formaldehyde:

$$
\begin{aligned}
& \mathrm{PAN} \longrightarrow \mathrm{NO}_{2}+\mathrm{CH}_{3} \mathrm{CO}_{3} \quad \text { (reverse of } 16 \mathrm{c} \text { ) } \\
& \mathrm{CH}_{3} \mathrm{CO}_{3}+\mathrm{NO} \longrightarrow \mathrm{NO}_{2}+\mathrm{CH}_{3} \mathrm{CO}_{2} \\
& \mathrm{CH}_{3} \mathrm{CO}_{2} \longrightarrow \mathrm{CH}_{3}+\mathrm{CO}_{2}
\end{aligned}
$$

followed by oxidation of $\mathrm{CH}_{3}$ to formaldehyde via the reaction sequence $15 \mathrm{c}-15 \mathrm{e}$ shown above.

In urban areas that make use of ethanol as a fuel, e.g. São Paulo and other major cities in Brazil, the atmospheric oxidation of ethanol produces acetaldehyde, which is also emitted directly by vehicles that use ethanol ${ }^{29}$ and ethanolgasoline mixtures. Ambient levels of acetaldehyde have been measured in Sao Paulo and Rio de Janeiro ${ }^{30}$ and are high when compared to those of other urban areas of the world that do not use ethanol as a fuel. In turn, the oxidation of acetaldehyde, including that resulting from the use of ethanol-fueled vehicles, leads to PAN which has been measured in Rio de Janeiro ${ }^{31}$ and is currently being measured in Porto Alegre ${ }^{32}$. The adverse effects of PAN on human health and on ecosystems ${ }^{33}$ have received worldwide attention from researchers and air pollution control agencies.

\section{2-propanol}

The reaction of 2-propanol with $\mathrm{OH}$ has not been studied. Ohta et al. ${ }^{22}$ have studied the reaction of 2-propanol with chlorine atoms and have identified acetone as the major product. The relevant reactions are:

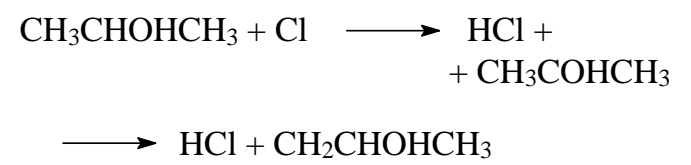

followed by reaction of the $\alpha$-hydroxyalkyl radical $\mathrm{CH}_{3} \mathrm{COHCH}_{3}$ with oxygen by $\mathrm{H}$-atom abstraction:

$\mathrm{CH}_{3} \mathrm{COHCH}_{3}+\mathrm{O}_{2} \longrightarrow \mathrm{HO}_{2}+\mathrm{CH}_{3} \mathrm{COCH}_{3}$ 
Thus, the atmospheric oxidation of 2-propanol may be described by two reactions, i.e. reaction with $\mathrm{OH}$ (reaction $5 a)$ followed by reaction 18 . Unlike acetaldehyde, which is more reactive than its precursor ethanol, acetone is less reactive than its precursor 2-propanol. Removal of acetone from the atmosphere is slow and involves photolysis and reaction with $\mathrm{OH}$. The resulting products include formaldehyde and, in the presence of NOx, peroxyacetyl nitrate ${ }^{34}$.

\section{2-butanol}

The reaction of 2-butanol with $\mathrm{OH}$ has been studied by Carter et $_{\text {al. }}{ }^{24}$, who identified 2-butanone (yield $=75-80 \%$ ) and acetaldehyde (yield $=12-16 \%$ ) as the major products. The reaction of $\mathrm{OH}$ with 2-butanol may involve up to five $\mathrm{H}$-atom abstraction pathways:

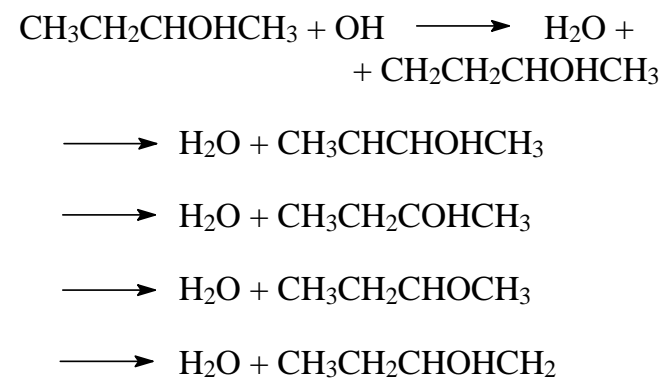

The observation of 2-butanone and acetaldehyde as major products, together with kinetic considerations and measured yields of minor products as discussed in detail by Carter et al. $^{24}$, shows that only two of the above five pathways are important: reaction 19c (major), which involves $\mathrm{H}$-atom abstraction from the tertiary $\mathrm{C}-\mathrm{H}$ bond, and reaction $19 \mathrm{~b}$, which involves $\mathrm{H}$-atom abstraction from the secondary C-H bond. The other three pathways, 19a, 19d and 19e, each accounted for $\leq 2 \%$ of the overall 2-butanol$\mathrm{OH}$ reaction.

The $\alpha$-hydroxyalkyl radical formed in (19c) reacts with oxygen by $\mathrm{H}$-atom abstraction, yielding 2-butanone:

$$
\begin{array}{ll}
\mathrm{CH}_{3} \mathrm{CH}_{2} \mathrm{COHCH}_{3}+\mathrm{O}_{2} \longrightarrow & \mathrm{HO}_{2}+ \\
+ & \mathrm{CH}_{3} \mathrm{CH}_{2} \mathrm{COCH}_{3}(20)
\end{array}
$$

and the alkyl radical formed in (19b) reacts with oxygen by addition, leading to $\mathrm{HO}_{2}$ and two molecules of acetaldehyde:

$$
\mathrm{CH}_{3} \mathrm{CHCHOHCH}_{3}+\mathrm{O}_{2} \longrightarrow
$$

$\mathrm{CH}_{3} \mathrm{CH}\left(\mathrm{O}_{2}\right) \mathrm{CHOHCH}_{3}$

$$
\begin{aligned}
\mathrm{CH}_{3} \mathrm{CH}\left(\mathrm{O}_{2}\right) \mathrm{CHOHCH}_{3}+\mathrm{NO} & \longrightarrow \\
\mathrm{NO}_{2}+\mathrm{CH}_{3} \mathrm{CH}(\mathrm{O}) \mathrm{CHOHCH}_{3} & \\
\mathrm{CH}_{3} \mathrm{CH}(\mathrm{O}) \mathrm{CHOHCH}_{3} \longrightarrow & \begin{array}{l}
\mathrm{CH}_{3} \mathrm{CHO}+ \\
+\mathrm{CH}_{3} \mathrm{CHOH}
\end{array} \\
\mathrm{CH}_{3} \mathrm{CHOH}+\mathrm{O}_{2} \longrightarrow & \mathrm{HO}_{2}+\mathrm{CH}_{3} \mathrm{CHO}
\end{aligned}
$$

The subsequent reactions of acetaldehyde have been described above, see reactions $15 \mathrm{a}-15 \mathrm{e}$ (photolysis) and reactions 16a-16e (reaction with $\mathrm{OH}$ ). The reactions of 2-butanone include photolysis and reaction with $\mathrm{OH}$. These reactions lead to acetaldehyde, PAN, formaldehyde, methyl nitrate and ethyl nitrate ${ }^{24}$.

\section{2-methyl-2-propanol (t-butyl alcohol)}

The reactions of t-butyl alcohol with $\mathrm{OH}$ and with $\mathrm{Cl}$ have been studied by Cox and Goldstone ${ }^{25}$ and by Japar $e t$ $a .^{26}$, respectively. Acetone was the only product reported by Cox and Goldstone. Japar et al. reported acetone and formaldehyde in unit yields, i.e. t-butyl alcohol $+\mathrm{OH} \rightarrow$ 1.0 acetone +1.0 formaldehyde. The reaction mechanism is simpler than for other alcohols since the initial step involves only one $\mathrm{H}$-atom abstraction pathway:

$$
\begin{aligned}
\left(\mathrm{CH}_{3}\right)_{3} \mathrm{COH}+\mathrm{OH} \longrightarrow & \mathrm{H}_{2} \mathrm{O}+ \\
& +\mathrm{CH}_{2} \mathrm{C}(\mathrm{OH})\left(\mathrm{CH}_{3}\right)_{2}
\end{aligned}
$$

followed, as for all alkyl radicals, by the reaction sequence $\mathrm{R}+\mathrm{O}_{2} \rightarrow \mathrm{RO}_{2}, \mathrm{RO}_{2}+\mathrm{NO} \rightarrow \mathrm{RO}+\mathrm{NO}_{2}$. The alkoxy radical $\mathrm{RO}$ then decomposes by $\mathrm{C}-\mathrm{C}$ bond cleavage:

$$
\begin{aligned}
\mathrm{OCH}_{2} \mathrm{C}(\mathrm{OH})\left(\mathrm{CH}_{3}\right)_{2} \longrightarrow & \mathrm{HCHO}+ \\
& +\mathrm{CH}_{3} \mathrm{COHCH}_{3}
\end{aligned}
$$

and the a-hydroxyalkyl radical $\left(\mathrm{CH}_{3}\right)_{2} \mathrm{COH}$ reacts with oxygen to yield acetone, as discussed above for 2-propanol:

$$
\mathrm{CH}_{3} \mathrm{COHCH}_{3}+\mathrm{O}_{2} \longrightarrow \mathrm{CH}_{3} \mathrm{COCH}_{3}+\mathrm{HO}_{2}
$$

The observation by Japar $e t$ al. $^{26}$ of acetone and formaldehyde, each with yields of 1.0, implies that reaction of the alkoxy radical $\mathrm{OCH}_{2} \mathrm{C}(\mathrm{OH})\left(\mathrm{CH}_{3}\right)_{2}$ with oxygen is negligible and does not compete with decomposition (reaction 22) under conditions relevant to the atmosphere.

\section{2,4-dimethyl-2-pentanol and 3,5-dimethyl-3-hexanol}

These two branched-chain alcohols, $\mathrm{RCH}_{2} \mathrm{COH}\left(\mathrm{CH}_{3}\right)$ $\mathrm{CH}_{2} \mathrm{CH}\left(\mathrm{CH}_{3}\right)_{2}$, with $\mathrm{R}=\mathrm{H}$ and $\mathrm{R}=\mathrm{CH}_{3}$ respectively, have been studied by Atkinson and Aschmann ${ }^{14}$ in experiments involving the photolysis of methyl nitrite $\left(\mathrm{CH}_{3} \mathrm{ONO}\right)$ as the source of $\mathrm{OH}$. These two alcohols, for which a detailed study of reaction products was carried out, were investigated with the objective of seeking evidence for isomerization of alkoxy radicals ${ }^{14}$. While this topic is outside of the scope of this review, we note that the major carbonyl products and the corresponding reaction mechanisms are entirely consistent with those described above for lower molecular weight alcohols. Thus, the observation of acetone (yield $=0.92$ ) from 2,4-dimethyl-2-pentanol and of acetone and 2-butanone (yields $=0.12$ and 0.27 respectively) from 3,5-dimethyl-3-hexanol indicate that a major pathway in the reaction of $\mathrm{OH}$ with these branched-chain alcohols involves, as we have discussed before (see for 
example 2-propanol), $\mathrm{H}$-atom abstraction from the weakest (tertiary) $\mathrm{C}-\mathrm{H}$ bond:

$$
\begin{array}{r}
\mathrm{RCH}_{2} \mathrm{COH}\left(\mathrm{CH}_{3}\right) \mathrm{CH}_{2} \mathrm{CH}\left(\mathrm{CH}_{3}\right)_{2}+\mathrm{OH} \longrightarrow \\
\mathrm{H}_{2} \mathrm{O}+\mathrm{RCH}_{2} \mathrm{COH}\left(\mathrm{CH}_{3}\right) \mathrm{CH}_{2} \mathrm{C}\left(\mathrm{CH}_{3}\right)_{2}
\end{array}
$$

followed by the sequence $\mathrm{R}+\mathrm{O}_{2} \rightarrow \mathrm{RO}_{2}, \mathrm{RO}_{2}+\mathrm{NO} \rightarrow$ $\mathrm{NO}_{2}+\mathrm{RO}$ and by decomposition of the corresponding alkoxy radical, yielding acetone from each alcohol:

$$
\begin{array}{r}
\mathrm{RCH}_{2} \mathrm{COH}\left(\mathrm{CH}_{3}\right) \mathrm{CH}_{2} \mathrm{CO}\left(\mathrm{CH}_{3}\right)_{2} \longrightarrow \\
\mathrm{CH}_{3} \mathrm{COCH}_{3}+\mathrm{RCH}_{2} \mathrm{COH}\left(\mathrm{CH}_{3}\right) \mathrm{CH}_{2}
\end{array}
$$

The alkyl radical $\mathrm{RCH}_{2} \mathrm{COH}\left(\mathrm{CH}_{3}\right) \mathrm{CH}_{2}$ that forms in reaction 24 undergoes the same sequence, leading to the alkoxy radical $\mathrm{RCH}_{2} \mathrm{COH}\left(\mathrm{CH}_{3}\right) \mathrm{CH}_{2} \mathrm{O}$ and subsequently to formaldehyde (which was not measured) and to acetone from 2,4-dimethyl-2-pentanol and 2-butanone from 3,5-dimethyl-3-hexanol:

$$
\begin{aligned}
& \mathrm{RCH}_{2} \mathrm{COH}\left(\mathrm{CH}_{3}\right) \mathrm{CH}_{2} \mathrm{O} \longrightarrow \\
&+\mathrm{RCH}_{2} \mathrm{COHCH}_{3} \\
& \mathrm{RCH}_{2} \mathrm{COHCH}_{3}+\mathrm{O}_{2} \longrightarrow \mathrm{HO}_{2}+ \\
&+\mathrm{RCH}_{2} \mathrm{COCH}_{3} \text { acetone }(\mathrm{R}=\mathrm{H}) \\
& \\
& \text { 2-butanone }(\mathrm{R}=\mathrm{CH} 3)
\end{aligned}
$$

\section{Conclusions and suggestions for future research}

The kinetic and product studies reviewed in this article have yielded much information about the persistence and reactions of alcohols in the atmosphere. Kinetic studies indicate that the atmospheric persistence of alcohols is $c a$. one week for methanol and t-butyl alcohol, two and a half days for ethanol, and ca. 8-15 h for the higher molecular weight alcohols. A major finding of the several product studies that have been carried out has been to establish that, unlike other alkyl radicals which react with oxygen by addition $\left(\mathrm{R}+\mathrm{O}_{2} \rightarrow \mathrm{RO}_{2}\right.$ ), $\alpha$-hydroxyalkyl radicals react with oxygen by $\mathrm{H}$-atom abstraction, leading to a carbonyl and $\mathrm{HO}_{2}$. Thus, for the several $\alpha$-hydroxyalkyl radicals studied to date, atmospheric oxidation can be written as follows (the precursor alcohol is indicated in brackets):

$$
\begin{aligned}
& \mathrm{CH}_{2} \mathrm{OH}+\mathrm{O}_{2} \longrightarrow \mathrm{HO}_{2}+\mathrm{HCHO} \text { [methanol] (10a) } \\
& \mathrm{CH}_{3} \mathrm{CHOH}+\mathrm{O}_{2} \longrightarrow \underset{+\mathrm{CH}_{3} \mathrm{CHO}}{\mathrm{HO}_{2}+} \text { [ethanol] } \\
& \left(\mathrm{CH}_{3}\right)_{2} \mathrm{COH}+\mathrm{O}_{2} \longrightarrow \mathrm{HO}_{2}+ \\
& +\mathrm{CH}_{3} \mathrm{COCH}_{3} \text { [2-propanol] } \\
& \mathrm{CH}_{3} \mathrm{CH}_{2} \mathrm{C}(\mathrm{OH}) \mathrm{CH}_{3}+\mathrm{O}_{2} \longrightarrow \mathrm{HO}_{2}+ \\
& +\mathrm{CH}_{3} \mathrm{COCH}_{2} \mathrm{CH}_{3} \text { [2-butanol] }
\end{aligned}
$$

There appears to be sufficient kinetic data to calculate the atmospheric half-lives of many alcohols, see Table 1. In contrast, only limited information is available regarding the products of the $\mathrm{OH}$-alcohol reaction. There have been only two studies of methanol (both with $\mathrm{Cl}$ and none with $\mathrm{OH}$ ), one of ethanol, one of 2-propanol (with $\mathrm{Cl}$, not with $\mathrm{OH})$, none for 1-propanol, none for 1-butanol, one for 2-butanol and two for t-butyl alcohol. While these studies have established the major features of the $\mathrm{OH}$ reaction for a few alcohols, there are still substantial gaps in our understanding of the oxidation of alcohols in the atmosphere. For example, in the case of ethanol which is widely used as a vehicle fuel in Brazil and elsewhere, it appears important to study the branching ratio between the ethanol $+\mathrm{OH} \rightarrow$ (acetaldehyde + PAN) vs. ethanol $+\mathrm{OH} \rightarrow$ (formaldehyde and / or hydroxyacetaldehyde) pathways, reactions 3a and 13 vs. reactions $3 \mathrm{~b}$ and $14 \mathrm{a}-14 \mathrm{~d}$, respectively. This is because a yield of $80 \pm 15 \%$ for acetaldehyde is reported in the only study of ethanol to date ${ }^{24}$, thus leaving a large uncertainty, i.e. 5-35\% of the overall $\mathrm{OH}$-ethanol reaction, for the magnitude of pathway $3 \mathrm{~b}$.

Reflecting the concern about the air pollution control aspects of using alcohols as vehicle fuels, there has been in recent years a number of studies that have focused on ozone formation from many hydrocarbons including alcohols ${ }^{35-}$ 38. These recent studies, however comprehensive in their scope, have unfortunately not yielded new information on reaction products and on the mechanism of the alcohol-OH reaction. More product studies are needed to improve our understanding of the reaction of alcohols in the atmosphere and of the impact of alcohols, emitted as vehicle fuels and industrial solvents, on urban and regional air quality.

\section{Acknowledgments}

Ms. Brenda Brennan prepared the draft and final versions of the manuscript. Mr. Eric Grosjean (DGA, Inc.) and Professor Jailson B. de Andrade (UFBa, Salvador, Bahia) provided input and comments on the draft manuscript. This work was supported by internal R \& D funds, DGA, Inc., Ventura, CA.

\section{Note Added in Proof}

Stemmler et al. (Environ. Sci. Technol. 1996, 30, 3385; J. Phys. Chem. 1996, 100, 2114) have reported kinetic and product data for the reaction of $\mathrm{OH}$ with 2-ethoxyethanol and other glycol ethers.

\section{References}

1. Grosjean, D. Química Nova 1995, 18, 184.

2. McDonald, R.C.; Fall, R. Atmos. Environ. 1993, 27A, 1709.

3. Knig, G.; Brunda, M.; Puxbaum, H.; Hewitt, C.N.; Duckham, S.C. Atmos. Environ. 1995, 29, 861.

4. Toxicological and Performance Aspects of Oxygenated Motor Vehicle Fuels. U.S. National Research Council, National Academy Press, Washington, D. C. (1996). 
5. Grosjean, D.; Grosjean, E.; Williams II, E.L. Environ. Sci. Technol. 1993, 27, 2478.

6. Grosjean, D.; Grosjean, E. J. Geophys. Res. 1995, 100, 22,815 .

7. Grosjean, D. Atmospheric Chemistry of Ethers. In preparation, 1996.

8. Atkinson, R. Atmos. Environ. 1990, 24A, 1.

9. Atkinson, R. Chem. Rev. 1986, 86, 69.

10. Hess, W.P.; Tully, F.P. J. Phys. Chem. 1989, 93, 1944.

11. Wallington, T.J.; Kurylo, M.J. Int. J. Chem. Kinetics 1987, 19, 1015.

12. Wallington, T.J.; Dagaut, P.; Liu, R.; Kurylo, M.J. Int. J. Chem. Kinetics 1988, 20, 541.

13. Wallington, T.J.; Dagaut, P.; Liu, R.; Kurylo, M.J. Environ. Sci. Technol. 1988, 22, 842.

14. Atkinson, R.; Aschmann, S. Environ. Sci. Technol. 1995, 29, 528 .

15. Niki, H.; Maker, P.D.; Savage, C.M.; Hurley, M.D. J. Phys. Chem. 1987, 91, 2174.

16. Dagaut, P.; Liu, R.; Wallington, T.J.; Kurylo, M.J. J. Phys. Chem. 1989, 93, 7838.

17. Anderson, L.G. Int. J. Chem. Kinetics 1988, 20, 103.

18. Nelson, L.; Rattigan, O.; Neavyn, R.; Sidebottom, H.; Treacy, J.; Nielsen, O.J. Int. J. Chem Kinetics 1990, $22,1111$.

19. Payne, W.A.; Brunning, J.; Mitchell, M.B.; Stief, L.J. Int. J. Chem. Kinetics 1988, 20, 63.

20. Wallington, T.J.; Skewes, L.M.; Siegl, W.O.; Wu, C-H.; Japar, S.M. Int. J. Chem. Kinetics 1988, $20,867$.

21. Sniderm J.R.; Dawson, G.A. J. Geophys. Res. 1985, 90, 3797.

22. Ohta, T.; Bandow, H.; Akimoto, H. Int. J. Chem. Kinetics 1982, 14, 173.

23. Whitbeck, M. Atmos. Environ. 1983, 17, 121.
24. Carter, W.P.L.; Darnall, K.R.; Graham, R.A.; Winer, A.M.; Pitts-Jr., J.N. J. Phys. Chem. 1979, 83, 2305.

25. Cox, R.A.; Goldstone. A. In Proceedings of the 2nd European Symposium on the Physico Chemical Behavior of Atmospheric Pollutants; D. Riedel Pub. Co., Dordrecht, Holland, pp 112-119 (1982).

26. Japar, S.M.; Wallington, T.J.; Richart, J.F.O.; Bell, J.C. Int. J. Chem. Kinetics 1990, 22, 1257.

27. Miyoshi, A.; Matsui, H.; Washida, N. J. Phys. Chem. 1990, 94, 3016.

28. Wallington, T.J.; Andino, J.M.; Kaiser, E.W.; Japar, S.M. Int. J. Chem. Kinetics 1989, 21, 1113.

29. de Andrade, J.B.; Miguel, A.H. Int. J. Environ. Anal. Chem. 1985, 21, 229.

30. Grosjean, D.; Miguel, A.H.; Tavares, T.M. Atmos. Environ. 1990, 24B, 101.

31. Tanner, R.L.; Miguel, A.H.; de Andrade, J.B;. Gaffney, J.S.; Strait, G.E. Environ Sci. Technol. 1988, 22, 1026.

32. Grosjean, E.; Grosjean, D. Unpublihed results, DGA, Inc., Ventura, CA, U.S.A. 1996.

33. Grosjean, E.; Grosjean, D.; Fraser, M.P.; Cass., G.R. Environ. Sci. Technol. 1996, 30, 2704.

34. Carter, W.P.L. Atmos. Environ. 1990, 24A, 481.

35. Carter, W.P.L. J. Air Waste Manag. Assoc. 1994, 44, 881.

36. Japar, S.M.; Wallington, T.J.; Rudy, S.J.; Chang, T.Y. Environ. Sci. Technol. 1991, 25, 415.

37. Carter, W.P.L.; Pierce, J.A.; Luo, D.; Malkina, I.L. Atmos. Environ. 1995, 29, 2499.

38. Carter, W.P.L. Atmos. Environ. 1995, 29, 2513. 